\title{
„Jeśli król przystąpi do konfederacji..." Rosja wobec Stanisława Augusta w 1792 r. (kwiecień-sierpień 1792 r.)
}

Zarys treści: Przystąpienie Stanisława Augusta do konfederacji targowickiej było jednym z czynników, które w istotny sposób zaważyły na losach Rzeczypospolitej. Król usprawiedliwiał ten krok beznadziejną sytuacją oraz wynikiem głosowania Straży Praw. Miał też nadzieję, iż przystępując do konfederacji, będzie mógł wpływać na jej dalszy kształt. W świetle nowych, nieznanych wcześniej archiwaliów rosyjskich można wysnuć wniosek, iż decyzja została podjęta zbyt szybko, co więcej, król nosił się z takim zamiarem już przed głosowaniem Straży. Jak się okazało, swoim działaniem osiągnął efekt przeciwny do oczekiwanego - nie tylko ułatwił Rosji pacyfikację kraju, ale pozbawił siebie jakiegokolwiek wpływu na dalsze wydarzenia.

Outline of content: The accession of King Stanislaw August to the Targowica Confederation was one of the factors that significantly influenced the fate of the Commonwealth. The king justified this step with a hopeless situation and the result of voting by the Guard of Laws. He also hoped that by joining the confederation, he would be able to influence its further shape. In the light of the new documents found in Russian archives, previously unknown to researchers, one can conclude that the decision was made too quickly and, moreover, the king was determined to make it without looking at the stance of the members of the Guard. As it turned out, he achieved the opposite effect than he expected - not only did he facilitate Russia's pacification of the country, but also he deprived himself of any influence on further events.

Słowa kluczowe: konfederacja targowicka, wojna polsko-rosyjska 1792, Stanisław August, Sejm Czteroletni, stosunki polsko-rosyjskie w okresie rozbiorów

Keywords: Targowica Confederation, Polish-Russian War of 1792, Stanislaw August, Four-Year Sejm, Polish-Russian relations during the partition period 
Przystąpienie Stanisława Augusta do Targowicy było jednym z najważniejszych wydarzeń, które w istotny sposób zaważyły na losach Rzeczypospolitej. Tragiczne następstwa, jakie miały miejsce po krótkim okresie rządów konfederacji targowickiej, sprawiły, iż bardzo szybko pojawiły się próby jej oceny i osądu ${ }^{1}$. Mimo upływu kolejnych lat temat ten wciąż wzbudza dyskusje i emocje, można też zauważyć wyraźny podział na dwa obozy - obrońców króla oraz jego przeciwników. Pierwsi usprawiedliwiają jego decyzję brakiem innych możliwości wyjścia $\mathrm{z}$ sytuacji, drudzy piętnują słaby charakter monarchy ${ }^{2}$. Dyskurs ten przez dziesięciolecia opierał się głównie na znajomości wydarzeń znanych z polskich przekazów źródłowych, bardzo często sprowadzał się do osobistych sympatii lub antypatii do króla (często bez głębszej wiedzy o faktach i okolicznościach wydarzeń 1792 r.). Tymczasem decydującym elementem tej oceny powinien być stosunek Rosji do postawy Stanisława Augusta, bowiem to od niej zależały wszelkie decyzje z tym związane. Nieznane wcześniej polskim badaczom archiwalia rosyjskie z tego okresu rzucają nowe światło na przełomowe wydarzenia z $1792 \mathrm{r}$.

W marcu i kwietniu 1792 r. w Petersburgu odbyły się finałowe rozmowy między głównymi rosyjskimi ministrami a grupą polskich i litewskich malkontentów $\mathrm{w}$ sprawie interwencji w Rzeczypospolitej, których celem było obalenie reform sejmu obradującego od $1788 \mathrm{r}$. i przywrócenie rosyjskiego protektoratu. Miały tego dokonać armia rosyjska i konfederacja zawiązana przez zgromadzonych nad Newą malkontentów. Rola siły militarnej była wiadoma, wojska winny złamać opór armii Rzeczypospolitej i zapewnić swobodne warunki do zawiązania lokalnych, a następnie generalnej konfederacji. Nie mniej ważny, jeśli nie ważniejszy był jednak aspekt polityczny, szczególnie legitymizacja interwencji i jej przebiegu. Uprawomocnieniu wszelkich działań miało służyć zawiązanie konfederacji i powołanie instytucji $\mathrm{z}$ nią związanych, kierujących państwem podczas jej trwania. W przypadku przyjęcia takiego kształtu interwencji, gdzie konfederacja (w założeniu organizatorów) miała dokonać przejęcia władzy, a następnie ją sprawować, podstawową sprawą było omówienie roli i znaczenia najwyższych władz Rzeczypospolitej, a właściwie w obecnej sytuacji - ustrojowej - króla Stanisława Augusta.

${ }^{1}$ O ustanowieniu i upadku konstytucyi polskiej 3go maja 1791, Metz 1793.

${ }^{2}$ Historię polemiki zwolenników i przeciwników Stanisława Augusta przedstawia pozycja: A. Zahorski, Spór o Stanisława Augusta, Warszawa 1990. Z późniejszych publikacji, których nie ujmuje już wspomniana książka (pomijając artykuły, teksty publicystyczne i wypowiedzi, których jest zbyt wiele, aby wszystkie wymienić), warto wskazać na biografie oraz inne wydawnictwa poświęcone królowi: K. Zienkowska, Stanisław August Poniatowski, Wrocław 1998; J. Michalski, Stanisław August Poniatowski, Warszawa 2009; A. Grześkowiak-Krwawicz, Wstęp, w: Pamiętniki króla Stanisława Augusta. Antologia, Warszawa 2013, s. 9-40; P. Ugniewski, Ludwik XVI - Stanisław August. Propagandowe wizerunki równoległe, Warszawa 2014. Warto również wymienić zbiorową pracę poświęconą monarsze i jego reformom - efekt cyklu wykładów na Zamku Królewskim: Stanisław August i jego Rzeczpospolita. Dramat państwa, odrodzenie narodu, red. A. Sołtys, Z. Zielińska, Warszawa 2010-2011, oraz opracowanie korespondencji Stanisława Augusta z Katarzyną II, opatrzonej wyjątkowo obszernym komentarzem: Correspondance de Stanislas-Auguste avec Catherine II et ses plus proches collaborateurs (1764-1796), oprac. Z. Zielińska, Kraków 2015. 
Kwestia ta zyskała szczególne znaczenie dla liderów przyszłej konfederacji, którzy prowadzili dotychczas politykę opozycyjną w stosunku do polskiego władcy. Od I rozbioru Rosja utrzymywała równowagę w Rzeczypospolitej, nie pozwalając malkontentom na uzyskanie przewagi nad monarchą ani też królowi na zdominowanie malkontentów ${ }^{3}$. Udział Stanisława Augusta w reformatorskim zrywie ostatniego sejmu stawiał go co prawda po stronie przeciwników Rosji, jednakże przebywający aktualnie nad Newą hetman wielki koronny Franciszek Ksawery Branicki, hetman polny koronny Franciszek Rzewuski, Szymon Kossakowski czy Szczęsny Potocki musieli dobrze pamiętać lata po I rozbiorze, kiedy to Petersburg niejednokrotnie udzielał poparcia polskiemu monarsze. Zatem zabezpieczenie się z ich strony, jeszcze przed wkroczeniem wojsk rosyjskich do Rzeczypospolitej, przed ewentualnym porozumieniem między królem a Rosją, czego efekt mogło stanowić odebranie im przywódczej roli w konfederacji i wpływu na rozwój wydarzeń, było czymś oczywistym.

W rosyjskim Archiwum Spraw Zagranicznych wśród archiwaliów dotyczących misji Karla Bühlera, przedstawiciela Rosji przy konfederacji targowickiej, tuż za instrukcją dla niego znalazły się dwa niezwykle interesujące dokumenty. Pierwszy zatytułowano „Articles à résoudre par Sa Majesté Impériale”. W sześciu punktach ministrowie kierujący polityką zagraniczną przedstawili kluczowe dla powodzenia konfederacji, a więc niezwykle ważne, wymagające osobistej decyzji Katarzyny II, problemy, z czego połowa dotyczyła Stanisława Augusta. W odniesieniu do monarchy pisano:

4. La confédération a besoin de finir par une Diète. Si la roi ne voudra pas la convoquer, la confédération devra-t-elle la convoquer elle-même?

5. Si le roi veut accéder à la confédération ce qu'il voudrait mieux éviter; quel est l'accès; selon lequel il doit accéder?

6. Si le roi accède et qu'il veuille composer faut-il entrer en composition avec lui ou non? Si jamais on consente à traiter avec le roi, le roi devient par-là partie contractante et voudra traiter; ou tout seul, ou bien à la tête de la Diète d'aujourd'hui. S'il voudra traiter tout seul, il n'en a pas le droit; et la Russie en s'y prêtant, reconnaitra pour le moment la monarchie

${ }^{3}$ K.M. Morawski, Pogląd na opozycje magnacka między pierwszym rozbiorem a Sejmem Czteroletnim, w: Studia historyczne wydane ku czci prof. W. Zakrzewskiego, Kraków 1908, s. 374-387; idem, Ignacy Potocki, cz. 1: 1750-1788, Kraków-Warszawa 1911; E. Rostworowski, Sprawa aukcji wojska na tle sytuacji politycznej przed Sejmem Czteroletnim, Warszawa 1957; Z. Zielińska, Ambasador Otto Stackelberg $w$ dobie wojny o sukcesję bawarska, w: eadem, Studia z dziejów stosunków polsko-rosyjskich w XVIII wieku, Warszawa 2001, s. 136-159; eadem, Geneza upadku orientacji rosyjskiej u progu Sejmu Czteroletniego w opinii ambasadora Stackelberga, „Wiek Oświecenia” (1999), nr 15, s. 57-93; E. Zielińska, Otto Magnus Stackelberg wobec projektu skonfederowania sejmu 1782 roku: przyczynek do praktyki polityki rosyjskiej w Rzeczypospolitej przed Sejmem Wielkim, „Kwartalnik Historyczny” 106 (1999), nr 4, s. 73-87; J. Michalski, Opozycja magnacka i jej cele w poczatkach Sejmu Czteroletniego, w: idem, Studia historyczne z XVIII i XIX wieku, t. 1, Warszawa 2007, s. 285-304; A. Danilczyk, Afera Dogrumowej a konsolidacja opozycji antykrólewskiej w latach 1785-1786, „Kwartalnik Historyczny” 111 (2004), nr 4, s. 47-81. 
et le monarque dans la personne du roi, ce qui est contre les principes de la Russie. S'il voudra traiter accompagné de la Diète, ceci mettra la confédération en contradiction avec elle-même; vu qu'elle a déclaré cette Diète illégal et lui a enjoint de se séparer. D’un manière ou d'outre, la voie de traiter devien[t] impraticable, d'autant plus que l'intérêt de la Russie et de la Pologne est de convenir sur les loix qui devient rétablir la République, convoquer une Diète ne pas entrer en capitulation avec le roi, mais lui dire: la République le veut [podkreślenie oryginalne] ${ }^{4}$.

Miejsce, w którym znalazło się pismo oraz czas jego powstania powinny sugerować, że autorem mógł być jeden z ministrów rosyjskiego Ministerstwa Spraw Zagranicznych, do którego ścisłego grona zaliczali się wicekanclerz Iwan Ostermann, Aleksander Bezborodko, faktyczny jego kierownik oraz Arkady Morkow związany politycznie z Płatonem Zubowem, faworytem Katarzyny II. I to raczej z tym ostatnim należy nie tyle łączyć omawiane pismo, co wskazać jako tego, który przedłożył je Katarzynie II. Osoba polskiego monarchy i jego ewentualny akces do konfederacji wywołała zapewne zainteresowanie wszystkich ministrów i stanowiła ważną sprawę w nadchodzących wydarzeniach, jednak to liderzy przyszłej konfederacji byli najbardziej zainteresowani tym, jak Stanisław August zostanie potraktowany przez carycę i jaki będzie miał wpływ na rozwój sytuacji. Warto zauważyć, iż w przytoczonym tekście każdy punkt zawierał nie tylko przedstawienie problemu, ale jednocześnie sugestię odpowiedzi, przy czym zwraca uwagę zapis 6, w którym podkreślono negatywne efekty ewentualnej współpracy z królem. Obawa przed uznaniem Stanisława Augusta za partnera politycznego jest charakterystyczna dla malkontentów, którzy wielokrotnie wcześniej rywalizowali z królem o łaski Petersburga. Prawdopodobnie więc to $\mathrm{z}$ ich inicjatywy takie pismo, przy wykorzystaniu bliskich relacji Szymona Kossakowskiego z faworytem carycy, zostało przedłożone Katarzynie II. Tezę tę potwierdza jedno ze sformułowań p. 6, które w identycznej formie znajdujemy w liście Kossakowskiego do Zubowa po akcesie Stanisława Augusta do konfederacji ${ }^{5}$.

Przytaczane wyżej punkty świadczą o tym, iż malkontenci, uprzedzając przystąpienie króla do Targowicy, już na przełomie marca i kwietnia 1792 r. zadbali, aby akces monarchy nie dawał mu możliwości wpływania na działania konfederacji.

Katarzyna II ustosunkowała się do każdego z omówionych zagadnień. W piśmie zatytułowanym „Réponse aux articles proposés à la décision de Sa Majesté Impériale" czytamy:

Ad. 4 La confédération a le droit de convoquer la Diète ou de devenir Diète elle-même et fera très bien d'exercer ce droit.

Ad. $5 \mathrm{Si}$ le roi veut accéder à la confédération il le fera dans la forme ordinaire comme $\mathrm{y}$ accèderait tout autre et comme il y en a eu des exemples précédents.

\footnotetext{
${ }^{4}$ Arhiv Vnešnej Politiki Rossijskoj Imperii (dalej: AVPRI), f. 79/6, d. 1476, k. 100-100v.

${ }^{5}$ S. Kossakowski do P. Zubowa, AVPRI, f. 79/6.
} 
Ad. 6 Accéder à la confédération c'est adopter ces principes et s'y soumettre. Il n'y a pas là lieu à traiter ni à composer. La confédération ou la Diète qui s'assemblera sous le lieu de la confédération délecteront la loi et chacun doit la reconnaitre et la respecter bien entendu que chacun sera traité avec les égards et la considération au rang qu'il occupe dans la République. Il ne s'en suit pas cependant que la confédération ne puisse et ne doive même rejeter tous ceux qu'elle aura sujet de soupçonner de n'y vouloir entrer que pour en troubler ou empêcher les opérations et les effets: cela regarde surtout ceux d'entre individus de la Diète de Varsovie qui ont été les principaux instigateurs et promoteurs de la révolution du 3 mai $1792^{6}$.

Powyższa opinia Katarzyny II oznacza, że Rosja na początku planów związanych z interwencją w Rzeczypospolitej, zgodnie z pragnieniami i sugestiami malkontentów, wykluczyła Stanisława Augusta z wpływu na rozwój wydarzeń po jego przystąpieniu do konfederacji.

$18 \mathrm{~V} 1792$ r. wojska rosyjskie w sile 95 tys. żołnierzy, pod dowództwem gen. Michaiła Kachowskiego, przekroczyły granicę z Rzecząpospolitą. Główne uderzenie skierowano na województwa południowo-wschodnie, a Wielkie Księstwo Litewskie miał zająć korpus Michaiła Kreczetnikowa.

Armia polsko-litewska znajdowała się dopiero w fazie budowy. Dywizja ukraińska, której dowództwo objął książę Józef Poniatowski, liczyła 17 tys. żołnierzy. W odwodzie znajdowała się dywizja wołyńsko-podolska pod dowództwem księcia Michała Lubomirskiego w sile 4535 ludzi oraz korpus rezerwowy liczący 5520 żołnierzy pod dowództwem gen. Józefa Zajączka. Mocnym punktem obrony miał być jeszcze Kamieniec Podolski, którego załoga wynosiła 2748 żołnierzy. Wielkie Księstwo Litewskie broniła mniejsza armia, licząca niecałe 14 tys. żołnierzy, w dodatku niefortunnie jej dowództwo powierzono nielojalnemu księciu Ludwikowi Würtembergowi, który był zięciem generała ziem podolskich Adama Kazimierza Czartoryskiego.

Józef Poniatowski po otrzymaniu informacji o wkroczeniu rosyjskich oddziałów z kilku kierunków, 26 maja nakazał odwrót do Winnicy w obawie przed okrążeniem. Uznał, że najlepszym rozwiązaniem będzie wycofanie wojsk na Wołyń, gdzie znajdowały się główna kwatera armii koronnej i magazyny z zaopatrzeniem. Z końcem maja do połączonych sił Poniatowskiego i gen. Michała Wielhorskiego pod Ułanowem dołączyły oddziały gen. Tadeusza Kościuszki, wciąż napływały też pomniejsze jednostki osłaniające wcześniej granice. Tak powiększony korpus zatrzymał się pod Lubarem w oczekiwaniu na rozwój sytuacji. Głównodowodzącego martwił brak obiecywanych posiłków oraz jasnych rozkazów z Warszawy. Prośby księcia wysyłane do króla o instrukcje pozostawały bez odpowiedzi. Nie było też pewnych wiadomości o ruchach wojsk rosyjskich. Tymczasem te wkroczyły do Winnicy, Pohrebyszcza i Pawołoczy. Po tygodniowym postoju w Winnicy gen. Kachowski zdecydował się okrążyć i zniszczyć obóz polski pod Lubarem.

${ }^{6}$ AVPRI, f. 79/6, d. 1476, k. 101v-102. 
Poniatowski szybko zorientował się w zamiarach Rosjan i nakazał odwrót do Połonnego, a gdy na miejscu okazało się, że obóz nie został dostatecznie ufortyfikowany, do Ostroga. Pod Zieleńcami połączył swe siły z oddziałami dowodzonymi przez Lubomirskiego. Tam też 18 czerwca doszło do bitwy z przednią strażą korpusu gen. Michaiła Goleniszczewa-Kutuzowa, w sile ponad 10 tys. żołnierzy, dowodzonej przez gen. Herkulesa Morkowa. Po intensywnych walkach Morkow ustąpił z pola walki. Poniatowski nie znając wielkości sił Rosjan, a także z powodu strat, zaniechał ścigania wycofujących się oddziałów. Morkow, który nie mógł przeżyć upokarzającej porażki, po odejściu wojsk polskich wrócił na pobojowisko i ogłosił się zwycięzcą.

Po krótkiej obronie Ostroga Polacy wycofali się do Dubna, gdzie książę Lubomirski miał założyć magazyny dla armii koronnej. Jednakże tam okazało się, że magazyny są niemal puste, a na jaw wyszły tajne rokowania księcia Michała Lubomirskiego z Kachowskim. To książę ukrył większość zaopatrzenia i amunicji, chcąc oddać je Rosjanom, a w zamian prosił głównodowodzącego wojskiem rosyjskim, aby nie bombardował Dubna, które było jego własnością. W tej sytuacji Poniatowski podjął decyzję o wycofaniu armii za Bug.

Wojsko rozpoczęło odwrót, a po kilku dniach, po przekroczeniu rzeki, dywizje połączyły się w Dubience. Ostatnim akordem kampanii koronnej była bitwa właśnie w tej miejscowości, gdzie wojska polskie próbowały uniemożliwić sforsowanie Bugu przez Rosjan. Dywizja dowodzona przez Kościuszkę skutecznie stawiała opór i dopiero obejście jej pozycji przez terytorium zza kordonu austriackiego zmusiło przyszłego naczelnika do odwrotu.

Po oddaniu linii Bugu armia koronna połączyła się w okolicy Chełma, po czym pomaszerowała w stronę Lublina. Mimo wycofania się tak głęboko na terytorium korony armia polska wciąż nie została rozbita i zachowała pełną sprawność bojową.

Kampania litewska przebiegała mniej korzystnie. Granice Wielkiego Księstwa Litewskiego Rosjanie przekroczyli 22 maja 1792 r. Ponieważ wojsko litewskie wycofywało się przed przeważającymi siłami wroga, w ciągu dwóch tygodni opanowano znaczną część terytorium Litwy. Sytuację armii litewskiej pogarszała w znacznym stopniu zdradziecka postawa księcia Würtemberga. Po jego zdymisjonowaniu dowództwo objął gen. Józef Judycki. Początkowo zamierzał on zorganizować obronę w oparciu o Mir, jednakże z powodu błędów w dowodzeniu oddziały litewskie zostały zmuszone do odwrotu, przez Nieśwież i Słonim, do Grodna. Tam też dołączył do nich gen. Michał Zabiełło, który z powodu aktualnej sytuacji na froncie zrezygnował z obrony Wilna. 14 czerwca Szymon Kossakowski wkroczył do stolicy księstwa, 19 czerwca zajęto Nieśwież, 20 czerwca - Kowno, a 25 czerwca - Słonim.

Odwołanie ze stanowiska Judyckiego i zastąpienie go M. Zabiełłą przyniosło pozytywne efekty; nie mogło już zmienić radykalnie sytuacji. Pod Zelwą przednia straż starła się z wojskami rosyjskimi, które poniosły znaczne straty. Dzielnie broniono Brześcia, gdzie Rosjanie ostatecznie zdobyli miasto, ale okupili to tak 
wielkimi stratami, że nie ścigali obrońców. Po raz ostatni wojska litewskie starły się z Rosjanami pod Grannem. Wtedy to oddziały dowodzone przez M. Zabiełłę pokonały wojska rosyjskie pod dowództwem Fiodora Denisowa ${ }^{7}$.

Śledząc przebieg zmagań wojennych, z pozoru jednoznacznie daje się zauważyć przewagę wojsk rosyjskich. Pozornie, gdyż po głębszej analizie osiągniętych celów Petersburga $\mathrm{w}$ stosunku do założeń poczynionych nad Newą u progu kampanii okazuje się, że ta przewaga nie była wystarczająca na tyle, aby te cele zrealizować. Zakładano szybkie zwycięstwo, zlikwidowanie polskiej armii (już w pierwszych 2-3 tygodniach) i masowy akces szlachty do konfederacji ${ }^{8}$, tymczasem mimo zajęcia dużego terytorium Rzeczypospolitej żadne założenie nie zostało spełnione. Nie udało się też stworzyć armii konfederackiej. W pierwszej połowie czerwca generalność uchwaliła powołanie dwóch brygad kawalerii narodowej, ukraińskiej i podolskiej, oraz dwóch pułków lekkokonnych, jednakże rozporządzenia nie zostały niezrealizowane. Jeńcy $\mathrm{z}$ armii Poniatowskiego, siłą wcielani do tych oddziałów, uciekali przy pierwszej nadarzającej się okazji ${ }^{9}$.

Na zajętych przez wojska rosyjskie ziemiach, pomimo starań targowickich przywódców, zawiązywanie lokalnych konfederacji następowało bardzo wolno, nawet w województwach, w których malkontenci mieli znaczące wpływy. Większość powiatowych urzędników powyjeżdżała, część wstrzymywała się z decyzją, do konfederatów odnoszono się z dystansem lub wrogo. Hetman Branicki uciekł się do użycia siły - wojska rosyjskie niszczyły majątki opornych, zaś osobom, które nie przystąpią do konfederacji, grożono konfiskatą majątków - z trudem skonfederował w pierwszej połowie lipca województwa czernichowskie i wołyńskie, a w drugiej połowie kijowskie. Konfederowanie ziem Wielkiego Księstwa Litewskiego przebiegało „sprawniej”, ale głównie ze względu na brutalny charakter postępowania Szymona Kossakowskiego. W powiatach i ziemiach litewskich wojsko litewskie siłą gromadziło szlachtę, nawet w niewielkiej ilości, i zmuszało do zawiązywania konfederacji. Szlachcie stawiającej opór groziła konfiskata majątków. Kolejne konfederacje zawiązywały się, ale opornie, pod przymusem, przy niewielkiej frekwencji szlachty. Najlepiej mizerię konfederackiej akcji odzwierciedla sytuacja, która miała miejsce w Wilnie w momencie zawiązywania konfederacji generalnej litewskiej na pierwsze spotkanie nie przybył ani jeden urzędnik, przez co nie można było jej zalegitymizować, ostatecznie zawiązano ją w sposób odbiegający od normy (dwaj najważniejsi obrani urzędnicy, marszałek, kanclerz Sapieha i jego zastępca, łowczy wielki litewski Józef Zabiełło byli nieobecni) ${ }^{10}$.

7 Najpełniejszą monografią wojny 1792 r. jest pozycja: A. Wolański, Wojna polsko-rosyjska 1792 r., Warszawa 1996. Z innych tytułów warto wymienić również prace: T. Korzon, Dzieje wojen i wojskowości w Polsce, t. 3: Dokończenie epoki przedrozbiorowej, Warszawa 2003; K. Górski, Wojna 1792 r., Kraków 1917.

${ }^{8}$ A. Wolański, op. cit., s. 23-27.

9 W. Smoleński, Konfederacja targowicka, Kraków 1903, s. 86-87.

10 Ibidem, s. 111-125. 
Tak więc, co szczególnie podkreślmy, do połowy lipca Rosjanom nie udało się zrealizować zakładanych celów ani politycznych, ani militarnych. Armia polska nie została rozbita, wycofała się w głąb kraju, gdzie mogła liczyć na szybsze zaopatrzenie i posiłki. Jak zauważył Adam Wolański, autor najobszerniejszej i najlepiej dotychczas opracowanej monografii kampanii 1792 r., główne siły wojsk polskich i litewskich zostały zachowane, a straty osobowe były niewielkie ${ }^{11}$. Warto też wspomnieć o wysokim morale żołnierzy. Ci, którzy byli najbardziej narażeni w tej wojnie, w nieustannym odwrocie w dzień i w nocy, niewyspani i głodni, okazali największe oburzenie i niezadowolenie po otrzymaniu informacji o przystąpieniu króla do konfederacji targowickiej i rozkazu zawieszenia działań wojennych ${ }^{12}$.

$\mathrm{W}$ przeciwieństwie do wojsk polsko-litewskich oddziały rosyjskie znalazły się w głębi wrogiego terytorium, wydłużyły niezmiernie linie zaopatrzeniowe, a przede wszystkim ich jednostki, zmuszone do pozostawienia w miastach garnizonów narzucających siłą nową władzę, zostały rozproszone, tracąc swą zdolność bojową. Należy ten ostatni fakt zdecydowanie podkreślić, gdyż jest to opinia jednego z głównych dowódców wojsk rosyjskich.

Oficjalne raporty rosyjskich dowódców wysyłane do Petersburga brzmiały optymistycznie, jednakże z nieoficjalnej korespondencji wyłania się rzeczywisty, daleki od propagandy sukcesu, obraz sytuacji ${ }^{13}$. Niemal miesiąc po wkroczeniu na terytorium Rzeczypospolitej Kreczetnikow pisał do gen. Nikołaja Sałtykowa:

Откровенно донесу Вам, мой милостивый благодетель, что до сих пор, при всевозможном сохранении строгости воинской и спокойствия жителям, не видал я и тени того к нам их доброжелательства и податливости, которые прежде мне обещали и признательно доложу, что опасение только заставляет их повиноваться. Приверженность многих к Конституции 3-го мая, рассеянные повсеместно из Варшавы неприязненные разглашения и намериваемое там посполитое рушение не позволяют пропускать без особого внимания известий, подобных приложенному у сего в копии рапорта полоцкого таможенного советника [Гейдена] к Петру Богдановичу [Пассеку], а тем более, что оные могут иметь влияние и на многих белорусских дворян, имеющих поместья в Польше ${ }^{14}$.

W Petersburgu raporty o pozytywnej treści, otrzymywane od dowódców (bitwy pod Zieleńcami i Dubienką ogłoszono jako zwycięstwa), mogły i robiły dobre wrażenie na dworze, jednak w ścisłym kręgu decydentów zdawano sobie sprawę z niewielkich osiągnięć. Co więcej, niepokój „delegata” rosyjskiego przy

11 A. Wolański, op. cit., s. 686.

12 Ibidem, s. 689-690.

13 Zob. artykuł V. Anipiarkou, Konfederacja targowicka 1792 r.w świetle korespondencji stużbowej rosyjskiego generała Michaiła Kreczetnikowa w niniejszym zeszycie (s. 75-97).

${ }^{14}$ M.N. Kreczetnikow do N.I. Sałtykowa, [b.m.], 5/16 VI 1792, Rossiiskii gosudarstvennyi voenno-istoricheskii arkhiv (dalej: RGVIA), f. 41, op. 1/199, d. 174, k. 77v. Za udostępnienie odpisu dziękuję dr. Vadzimowi Anipiarkou. 
konfederacji musiał budzić fakt, iż brak sukcesów, na jakie niewątpliwie liczono, zaczął powodować konflikty wśród liderów samej konfederacji, gdzie coraz mocniej uwidaczniały się tarcia wynikające $\mathrm{z}$ różnych poglądów na ustrój państwa czy odmienny sposób działania. Szczęsny Potocki nie pochwalał na przykład siłowego konfederowania województw i gwałtownych metod stosowanych przez hetmana wielkiego koronnego Branickiego oraz Kossakowskich. Z kolei Kossakowscy wytykali Szczęsnemu, że konfederacje wojewódzkie na Litwie zawiązywały się o wiele szybciej niż w koronie, że wykazują się większą skutecznością. Nie wiadomo, jaką skalę mogłyby przybrać te niesnaski, gdyby nie akces króla do konfederacji, który - tym samym - załagodził nieporozumienia $\mathrm{w}$ jej łonie ${ }^{15}$.

Pod wpływem wyżej wymienionych czynników nad Newą zaczęto rozważać możliwość współpracy ze Stanisławem Augustem. Świadczy o tym list Zubowa do Bühlera, rosyjskiego przedstawiciela przy konfederacji. Faworyt carycy domagał się, aby na wypadek, gdyby król nie wykazał się rozsądkiem i „nie pozbawił Jej Imperatorskiej Wysokości [możliwości] bycia wspaniałomyślną dla niego i darowania jego błędów", Bühler zasięgnął opinii wśród liderów konfederacji w dwóch kwestiach:

1. Sur la manière d'envoyer les universaux pour la convocation de la Diète le roi n'étant pas de la confédération. 2. Sur le manière de la sommer à accéder à la confédération, s'il ne veut point perdre ses droits à la couronne en continuant de persister dans les principes de la constitution de 3 mai. Il est inutile Monsieur de vous recommander l'extrême circonspection que est nécessaire pour obtenir ces enseigneuses sans donner à soupçonner le moins $\mathrm{du}$ monde les desseins de la cour [podkreślenie - A.D.] ${ }^{16}$.

Źródło to jest niezwykle ważne, gdyż jeszcze w kwietniu, przed interwencją, uznano w Rosji, że konfederacja sama może zwołać sejm, a król przystąpić do Targowicy jak przeciętny szlachcic, bez monarszych przywilejów ${ }^{17}$. Jak widać, słabe postępy konfederacji zmusiły Petersburg do zrewidowania wcześniejszych poglądów i uwzględnienia negocjacji z królem. Ostrożność wobec liderów konfederacji, jaką miał zachować Bühler, sondując taką opcję, wynikała ze wspomnianych na początku tego artykułu obaw malkontentów, iż jakiekolwiek porozumienie między królem a Petersburgiem mogło ograniczyć ich wpływy w nowym układzie politycznym, a Rosja będzie dążyła do wcześniejszego systemu utrzymywania równowagi politycznej między monarchą a malkontentami. Zubow pozostający w bliskich kontaktach z Szymonem Kossakowskim miał tego świadomość. Taka sytuacja stwarzała zupełnie nowe możliwości nie tylko dla króla, ale dla całego dalszego układu sił politycznych. Niestety, nie została wykorzystana, gdyż Stanisław August, przekonany o beznadziejności sytuacji, przystąpił do Targowicy.

15 W. Smoleński, op. cit., s. 260-262.

16 P. Zubow do K. Bühlera, 22 VII / 2 VIII 1792, AVPRI, f. 79/6, d. 1489, k. 5v.

17 Zob. przypis 4 . 
Już po nieudanej misji Ignacego Potockiego do Berlina ${ }^{18}$, po której polscy politycy zrozumieli, iż nie można liczyć na wsparcie wojsk pruskich, podjęto starania o zawarcie jak najszybszego pokoju z Rosją. Na posiedzeniu Straży zdecydowano o wysłaniu do Katarzyny II listu z propozycjami pokojowymi. Pismo do imperatorowej zostało przedstawione ambasadorowi rosyjskiemu 21 czerwca, jednakże ten był niezadowolony z jego treści. Pod jego dyktando wprowadzono poprawki i kolejnego dnia wręczono je ponownie. Władysław Smoleński, autor monografii o konfederacji targowickiej, skłaniał się ku tezie, że poprawki te zostały naniesione przez króla bez wiedzy Straży ${ }^{19}$. Zważywszy na całkowitą uległość, widoczną w przesłanych punktach, można się zgodzić z historykiem, trudno bowiem uwierzyć, że taką formę zaakceptowałyby osoby, które po otrzymaniu odpowiedzi Katarzyny II głosowały za kontynuowaniem walki. Tym bardziej iż Jakow Bułhakow w swoich raportach pisanych do Petersburga bardzo przychylnie wyrażał się o dobrej (z punktu widzenia Rosjan) postawie polskiego monarchy ${ }^{20}$.

Zupełnie nowe światło na intencje i postawę Stanisława Augusta rzuca list Bułhakowa do Petersburga z 18 lipca, a więc jeszcze przed otrzymaniem odpowiedzi od Katarzyny II na propozycje Straży. Ambasador rosyjski pisał, iż kanclerz Joachim Chreptowicz, który bywa u niego na polecenie polskiego monarchy, poinformował, iż król zamierza postępować całkowicie za radą ambasadora rosyjskiego. Stanisław August proponował zwołanie sejmu i jego zakończenie (oficjalnie sejm zawiesił obrady), ewentualnie Chreptowicz podsuwał rozwiązanie sprawdzone kilkakrotnie w latach wcześniejszych - zwołanie senatus consilium, którym było łatwiej kierować i wymuszać ustępstwa. Ambasador za priorytet uznał przystąpienie do konfederacji, powołując się na podobne postępowanie króla w przeszłości, w przypadku konfederacji radomskiej.

Konsternację może budzić dalszy przekaz, w którym Chreptowicz wyraził obawy o bezpieczeństwo króla po przystąpieniu do konfederacji, zagrożone ze strony polskiego społeczeństwa, a które mogły zapewnić wojska rosyjskie, oraz usprawiedliwianie „wyjazdu” króla do obozu pod wpływem przymusu ze strony Stanisława Małachowskiego i Ignacego Potockiego ${ }^{21}$.

18 Zob. B. Dembiński, Polska na przełomie, Lwów 1913; idem, Misja Ignacego Potockiego w Berlinie w roku 1792, „Kwartalnik Historyczny” 51 (1937), nr 1-2.

19 W. Smoleński, op. cit., s. 137.

20 Zob. np.: J. Bułhakow do I.A. Ostermana, 7/18 VII 1792, AVPRI, f. 79/6, d. 1318, k. 28.

21 „Вице-канцлер Хрептович у меня бывает по приказанию короля, объявлял мне, что [они] намерены следовать во всем моим советам и, в следствие того, спрашивал у меня о многом, как например, [что] король намерен собрать сейм, объявить ему положение дел и разрушить его. Я отвечал: ничего вреднее быть не может для короля как сие собрание сейма и толковал ему опасность. Он согласился, предлагал созвать сенаторов на старинном основании или Senatus Consilium. Я отвечал, что ежели будет нужда, сие может быть сделано, когда конфедерация будет в Варшаве; но главная вещь есть та, чтоб король приступил к конфедерации, как то учинил во время Радомской. Он спрашивал о Совете тайном или дружеском, при короле оставить ли прежним? Придать ли к нему, кого 
W świetle powyższego przekazu funkcjonujące w polskiej historiografii opinie i oceny działań podjętych przez króla po otrzymaniu odpowiedzi od Katarzyny II, która dotarła do Warszawy 22 lipca, powinny zostać zweryfikowane ${ }^{22}$. Stanisław August skapitulował wcześniej, przed jej otrzymaniem, to nie powinno podlegać dyskusji. List Katarzyny II, w którym żądano kapitulacji i przystąpienia do konfederacji, dotarł, biorąc pod uwagę powyższe wydarzenia, w korzystnym dla króla momencie i stał się narzędziem wykorzystanym do zrealizowania tego celu, który pozwalał królowi uniknąć całkowitej odpowiedzialności za tę decyzję. W obliczu zdecydowania polskiego monarchy na kapitulację realizacja żądań Petersburga była tylko formalnością. W takiej sytuacji starania Stanisława Augusta, który wysłał Chreptowicza ponownie do ambasady rosyjskiej ze swoimi warunkami (chciał m.in. zapewnienia całości Polski, pozostawienia armii w aktualnym stanie, utrzymania władzy nad Komisją Skarbową i Wojskową do przybycia liderów konfederacji, zabezpieczenia pożyczek zaciągniętych przez Rzeczpospolitą), należy odczytać albo jako naiwność polityczną (kapitulując wcześniej, w tajemnicy, całkowicie zdawał się na łaskę Rosjan), albo próbę działań mających dać później argument do obrony własnej osoby. Bułhakow zażądał całkowitej uległości, wiedział przecież, że król podporządkuje się całkowicie woli Katarzyny II.

Wydaje się, że należy także zweryfikować spojrzenie na słynne posiedzenie Straży, które król zwołał 23 lipca. Zwolennicy stawiania dalszego oporu nie mieli świadomości, iż Stanisław August zawczasu był gotów przystąpić do Targowicy, a na spotkanie przybył z wyrobionym już postanowieniem. Wiedza, iż król podjął decyzję o poddaniu wcześniej, pomaga zrozumieć, dlaczego na posiedzeniu Straży znalazły się osoby, które nie powinny brać udziału w głosowaniu, co przechyliło szalę korzyści na zwolenników kapitulacji ${ }^{23}$.

я хочу? Или совсем составить новый и из кого? Я отвечал: лучше составить совет новый и наименовал ему особы, сказывал, что Малаховский и Потоцкий принуждали короля ехать в лагерь, стращали сделать против него позыв; и спрашивал, будет ли безопасен король, когда наши войска придут в Варшаву. Я отвечал: оставить королю Варшаву - было бы то побег; манифест пускай они делают, он ничего не значит и им во вред обратится; для короля не вижу я места безпечнее Варшавы, когда наши войска придут, но должно ему тот час подписать конфедерацию, чего теперь он, не подвергаясь явной опасности, учинить ещё не может. Спрашивал, не можно ли смягчить акта конфедерации. Я отвечал, что то будет зависеть от конфедерации, лишь бы желаемые смягчения не были противны Декларации, которая акту служит основанием", J. Bułhakow do I.A. Ostermana, ibidem, k. 24v-25v.

${ }^{22}$ Niektóre informacje o tym spotkaniu przytoczył S. Soloviev w Istorii padenia Polszi (Moskwa 2003). Za nim powtórzył to W. Smoleński, nie jest to jednak wierny przekład źródła - jedno spotkanie kanclerza Joachima Chreptowicza z 18 lipca i przedstawione przez niego propozycje króla rozbija na kilka wcześniejszych spotkań, co nie tylko wypacza fakty i kolejność wydarzeń, ale zmienia też odbiór i ocenę jakże ważnej deklaracji króla o kapitulacji z 18 lipca i jego postawy w kolejnych dniach, a przede wszystkim zebranie Straży i głosowanie 23 VII; W. Smoleński, op. cit., s. 200-201.

${ }^{23}$ Uczestniczyli w nim: prymas Michał Poniatowski, kanclerz Jan Małachowski, marszałek wielki koronny Michał Wandalin Mniszech i marszałek litewski Ignacy Potocki, marszałek nadworny 
Akces Stanisława Augusta zaniepokoił liderów konfederacji. W przeszłości niejednokrotnie okazywało się, że król w sytuacjach z pozoru bardzo niekorzystnych dla siebie potrafił przekonać Petersburg o swojej użyteczności, umacniając przy tym swoją pozycję jako rosyjskiego sojusznika. Tak było po I rozbiorze i ustanowieniu Rady Nieustającej.

Toteż tym razem obawa, iż monarcha może się jednak okazać partnerem politycznym w kontaktach z Rosją, wywołała histeryczne reakcje na akces i usilne próby jego zdyskredytowania przez przywódców konfederacji. Uwidoczniło się to w korespondencji przesyłanej rosyjskim decydentom. Na wypadek, gdyby Rosjanie przeoczyli rzeczywiste intencje króla, Seweryn Rzewuski przestrzegał Bühlera w pierwszych dniach sierpnia, że zamierzeniem dworu jest zawiązanie konfederacji w województwach, w których jeszcze to nie nastąpiło i uczynienie tego „przy królu"24. W efekcie monarcha mając wielu posłów na sejmie, mógłby wpływać na obrady według swojej woli. W tym duchu również Szymon Kossakowski ostrzegał swego przyjaciela Zubowa, pisząc, iż „chcieć tego, żeby coś jeszcze innego czynić, nic innego nie byłoby, jak zaprzeczyć całej konfederacji i zniszczyć ją zupełnie dla intrygi czyjejkolwiek wciśnienia ustronnych osób, nie spodziewam się przeto, żeby tej intrydze pobłażano"25. A że obawy malkontentów nie były bezpodstawne, dowodziły kolejne konfederacje, które powstawały przy królu, takie jak sandomierska, sieradzka, warszawska i wiele innych ${ }^{26}$.

litewski Stanisław Sołtan, podskarbi Tomasz A. Ostrowski, podskarbi wielki litewski Ludwik Tyszkiewicz, podskarbi nadworny litewski Antoni Dziekoński, podkanclerzy koronny Hugo Kołłątaj, litewski Joachim L. Chreptowicz, dwaj marszałkowie sejmowi Stanisław Małachowski i Kazimierz N. Sapieha. Na spotkaniu znalazł się jeszcze Kazimierz Poniatowski, który nie wchodził w skład Straży ani ministerium. Stanisław August przeczytał zebranym list od Katarzyny II, po czym nakreślił trudne położenie kraju. Następnie przedstawił swoją opinię na temat aktualnej sytuacji - nie widział sensu dalszej walki ze względu na szczupłość armii oraz przewagę wojsk rosyjskich. Podkreślił, iż Rzeczpospolita nie może również oczekiwać pomocy z zagranicy i zwrócił się do zebranych z zapytaniem o opinię w kwestii przystąpienia do konfederacji targowickiej. Po królu głos zabrali jego współpracownicy, którzy znani byli z prorosyjskiej opcji, opowiadając się za przyjęciem postulatów wroga: jego brat Michał Poniatowski, który optował za natychmiastowym przystąpieniem do targowicy, bliski współpracownik, a jednocześnie szwagier (mąż siostrzenicy) monarchy marszałek wielki koronny Michał Wandalin Mniszech, Joachim Litawor Chreptowicz i Antoni Dziekoński. Do tych głosów przyłączyli się też Ludwik Tyszkiewicz i Hugo Kołłątaj, ten ostatni sugerował, żeby rokowania prowadzić bezpośrednio z Rosją, z pominięciem targowiczan. Odmienne stanowisko prezentowali marszałek Stanisław Małachowski, podskarbi nadworny koronny Tomasz Ostrowski, Ignacy Potocki, marszałek nadworny litewski Stanisław Sołtan. Ignacy Potocki uznał nakreślony przez króla obraz sytuacji za przesadzony, widział też szanse na dalszą obronę. Padały propozycje kontynuowania walki, marszałek Małachowski proponował zwołanie sejmu, aby przedstawiciele kraju zadecydowali o dalszych krokach. Namawiano też monarchę do rzeczywistego objęcia dowództwa, a w ostateczności do opuszczenia kraju.

${ }^{24}$ S. Rzewuski do K. Bühlera, 23 VII / 3 VIII 1792, AVPRI, f. 79/6, d. 1483, k. 63, kopia.

${ }^{25}$ W. Smoleński, op. cit.

${ }^{26}$ Ibidem, s. 286-287. 
Szczęsny Potocki otrzymawszy list od króla o akcesie do konfederacji, jeszcze zanim otworzył dostarczoną korespondencję, poprosił Bühlera o natychmiastowe spotkanie. Przedstawiciel Rosji przy konfederacji miał równocześnie $\mathrm{z}$ adresatem poznać tekst warszawskich depesz ${ }^{27}$. Przy obiedzie został wypracowany plan działania zmierzający do całkowitego odsunięcia króla na boczny tor i pozbawienia go władzy. Bühler pisząc do Zubowa raport, przygotował jednocześnie „grunt” pod obraźliwą odpowiedź Szczęsnego Potockiego do króla na wcześniejszy list monarchy informujący o przystąpieniu do Targowicy ${ }^{28}$.

Stanisław August musiał więc przełknąć pierwszą gorzką pigułkę, jaką był list marszałka konfederacji - Szczęsnego Potockiego, który nie uznał pierwszego akcesu i zażądał jego powtórzenia przed konfederacją. Cały list napisany został w tonie niespotykanie obraźliwym dla króla; jego treść próbował bezskutecznie złagodzić (!) sam przedstawiciel Petersburga, Bühler ${ }^{29}$, a Szczęsny Potocki poczuł się w obowiązku wytłumaczyć z niego przed Katarzyną II i jej faworytem Zubowem. Prawdziwe swe intencje, po wydrukowaniu i rozprowadzeniu powyższej treści po kraju, wyjawił w liście do Kachowskiego: „Inaczej - pisał - przywiązać narodu do Moskwy nie można, jak tylko zwalając na króla całą nienawiść Polaków”30.

Monarcha musiał zmierzyć się $\mathrm{z}$ równie obraźliwą postawą Szymona Kossakowskiego, który 5 sierpnia przybył do Warszawy. Doszło do tego, że powagi należnej królewskiemu majestatowi bronił ambasador rosyjski (!), a w obronie monarchy stanęli nawet dowódcy wojsk rosyjskich. Kreczetnikow prosił bpa inflanckiego Józefa Kossakowskiego o przybycie i powstrzymanie brata, hetmana litewskiego od „wielu uchybień w postępowaniu” wobec króla: „Trzeba by zapobiec - pisał później do Zubowa - żeby konfederaci mniej znieważali króla, który, o ile mi wiadomo, znajduje się $\mathrm{z}$ tego powodu $\mathrm{w}$ stanie rozpaczliwym, obrony spodziewa się tylko od imperatorowej" ${ }^{\prime 3}$.

Decydujący głos w sprawie postawy Stanisława Augusta miała Katarzyna II. To ona mogła jednym rozkazem przywrócić mu prerogatywy i należną koronie godność. Imperatorowa nie zamierzała jednak bronić polskiego monarchy, całkowicie poparła plany liderów konfederacji zmierzające do wysłania delegacji do stolicy w celu odebrania królowi władzy oraz zmuszenia go do złożenia ponownego akcesu ${ }^{32}$. Szczególnie ten drugi element wart jest podkreślenia w odniesieniu

27 S. Potocki do K. Bühlera, [b.d.], AVPRI, f. 79/6, d. 1511, k. 22.

${ }^{28}$ K. Bühler do P. Zubowa, 21 VII / 1 VIII 1792, AVPRI, f. 79/6, d. 1483, k. 49v.

29 Bühler był tak zaskoczony ostrą formą, że w obawie przed ewentualną krytyką centrali napisał kilka dni później w tej sprawie ponownie, usprawiedliwiając się, że pewne sformułowania uznał za zbyt ostre, a Szczęsny Potocki zapewnił go o ich złagodzeniu, K. Bühler do P. Zubowa, 21 VII / 1 VIII 1792, AVPRI, f. 79/6, d. 1483.

30 W. Smoleński, op. cit., s. 239.

${ }^{31}$ Ibidem, s. 256.

32 „Акт приступления королевскаго, вам вручённый и сюда в копии присланный, мы и сами признали не достаточным, ибо в нём нимало не соблюдены те формы, каковыя взыскиваются конфедерационными узаконениями и обрядами: но мы оставили то без примечания, 
do stosunku carycy do polskiego monarchy, gdyż treść tego akcesu, ułożona przez Szczęsnego Potockiego, była dla Stanisława Augusta bardzo obraźliwa.

Królowi wyznaczono rolę biernego obserwatora i zażądano bezwzględnego posłuszeństwa. „Изъяснив его величеству точными словами” - nakazywała Katarzyna II ambasadorowi.

всё вышесказанное, прибав[ь]те, что мы ещё готовы не только забыть, что он и в торжественных объявлениях и в отзывах своих к наперстникам своим не усумнился нарекать нас своими неприятелями, но и продолжать в нынешнем его опасном состоянии подавать ему руку благотворительной помощи: но в замену того требуем неотменно, чтоб, отложа на сторону все замашки и все понушения вредить нашим непреложным намерениям, оставался он в совершенном спокойствии и полном недействии и ожидал бы в таковом положении развязки дела, которую мы не преминем направить таким образом, чтоб и честь его и все приличные его сану выгоды в полной мере предъохранены и обезпечены были. В противном же случае принуждены мы будем против воли нашей и с крайним огорчением предать его жребий праведному негодованию его народа, которое мы и сами с ним разделить долгом правосудия нашего почесть должны будем ${ }^{33}$.

Jeśli król liczył, iż składając akces do konfederacji, będzie, jak w przeszłości, partnerem do rozmów dla strony rosyjskiej i mieć wpływ na jej dalsze losy, przeliczył się. Najlepszymi tego dowodami były pozbawienie go realnej władzy przez przybyłą do Warszawy w drugiej połowie sierpnia delegację targowicką oraz wymuszenie powtórnego akcesu, którego treść ułożył Szczęsny Potocki w tonie upokarzającym monarchę.

Stanisław August nie miał pojęcia, że jego decyzja, u źródła której, jak twierdził, leżało przekonanie o ratowaniu państwa, trafiała w próżnię. Jako przywódca walczącego narodu był stroną, z którą mniej lub bardziej, ale jednak należało się liczyć. Po 22 lipca w Petersburgu nie zamierzano z nim prowadzić układów, gdyż poprzez swoje zaangażowanie w reformy sejmu 1788-1792 przestał być wiarygodny

сочтя сей акт предварительным обязательством, в разсуждении нас одних, и полагая, что недостатки, в нём находящиеся, исправлены будут, когда дело дойдёт со стороны его величества до прямаго и формальнаго приступления к конфедерации. Почему и не можем не признать основательным чинимое требование помянутою конфедерациею, чтоб тот акт составлен и подписан был в той силе и в той форме, в каковыя она чрез посылаемую в Варшаву депутацию представить его намеряется, и в следствие того повелеваем вам сие требование нашим именем подкреплять наисильнейше и доводить, конечно, до исполнения, естьли паче чаяния оное уже не воспоследовало", Katarzyna II do J. Bułhakowa, 3/14 VIII 1792, Biblioteka Polska w Paryżu, sygn. 29, nr 8, s. 1537-1538. Również w reskrypcie do Bühlera imperatorowa pochwaliła postępowanie liderów konfederacji: Katarzyna II do K. Bühlera, 3 VIII / 14 VIII 1792, AVPRI, f. 79/6, d. 1476, k. 122; Sbornik Russkogo Istoričeskogo Imperatorskogo Obščestva (SIRIO), t. 47, St. Petersburg 1885, s. 444.

${ }^{33}$ Katarzyna II do J. Bułhakowa, $3 / 14$ VIII 1792, Biblioteka Polska w Paryżu, sygn. 29, nr 8, s. 1541-1542. 
w oczach rosyjskich decydentów, a po jego akcesie do Targowicy nie było już siły mogącej przeszkodzić Rosji w realizowaniu imperialnych planów. Nie liczył się już jako partner polityczny, więc nie mógł utrudniać osiągnięcia celów rosyjskich wytyczonych wiosną 1792 r. Podkreślił to Bühler w liście do Zubowa po otrzymaniu informacji o przystąpieniu do konfederacji: „Que pourra-t-il faire le roi lorsqu'il n'aura plus ni ses conseillers pervers, ni l'armée ni le trésor de l'Ėtat?"34.

Król przystępując do Targowicy, osiągnął efekt przeciwny do oczekiwanego nie tylko ułatwił Rosji pacyfikację kraju, ale pozbawił siebie jakiegokolwiek wpływu na dalsze wydarzenia. Decyzja została podjęta zbyt szybko, a konsekwencje, które po części wywołała, poniosło całe państwo. Monarcha tłumaczył się przed swoimi współpracownikami z tego kroku, podkreślając, iż nie miał innego wyboru. Niestety, w świetle przedstawionych źródeł, jak wspomniano, wydaje się, że podjął decyzję zbyt szybko, a prowadzone przez niego $\mathrm{z}$ ambasadorem rosyjskim, $\mathrm{w}$ tajemnicy przed członkami Straży, prywatne, zakulisowe rozmowy zmierzające do kapitulacji i widoczna uległość, niezależnie od rzeczywiście trudnego położenia, w jakim znalazł się kraj, nie wystawiają najlepszej oceny polskiemu królowi.

\section{"If the King Accessed the Confederation..." Russia towards King Stanislaw August's Accession to Targowica Confederation in 1792 (April-August 1792)}

\section{Abstract}

The accession of King Stanislaw August to the Targowica Confederation was one of the factors that significantly influenced the fate of the Commonwealth. The king justified this step with a hopeless situation and the result of voting by the Guard of Laws. He also hoped that by joining the confederation, he would be able to influence its further shape.

Access to new documents in Russian archives, thus far unknown to researchers, made it possible to obtain information that sheds new light on the events of that time. They reveal that the course of the Polish-Russian war and the establishment of local confederations were negatively assessed by Russian commanders in chief, contrary to official propaganda. Nor the declarations of the Targowica leaders that, after the invasion of the Russian army, the nobility throughout the whole Polish Commonwealth would confederate and entrust themselves to Empress Catherine II fulfilled - this happened only in a few places and usually by force. It was also impossible to crush, despite the great advantage, the Polish-Lithuanian troops - although they retreated as far as the Bug River, but the forces were not broken and their morale improved. In St Petersburg, consideration was given to the possibility of negotiating with Stanislaw August. Thus, it can be concluded that the decision of Stanislaw August to join the confederation was taken too quickly; moreover, Russian sources reveal that the king was determined to make it without looking at the stance of the members of the Guard. As it turned out, he achieved the opposite effect than he expected - not only did he facilitate Russia's pacification of the country, but also he deprived himself of any influence on further events.

${ }^{34}$ K. Bühler do P. Zubowa, 21 VII / 1 VIII 1792, AVPRI, f. 79/6, d. 1483, k. 49v. 


\section{"Если король присоединится к конфедерации" Отношение России к Станиславу Августу в 1792 г. (апрель-август 1792 г.)}

\section{Аннотация}

Присоединение Станислава Августа к Тарговицкой конфедерации являлось одним из факторов, которые существенно повлияли на судьбу Речи Посполитой. Король оправдывал этот шаг безнадежным положением, а также результатом голосования Стражи законов. Он также надеялся, что присоединяясь к конфедерации сможет повлиять на ее дальнейшее формирование.

Доступ к российским архивным материалам, ранее неизвестным исследователям этого вопроса, дал возможность получить информацию, которая по-новому освещает тогдашние события. Из них следует, что ход польско-российской войны и образование местных конфедераций, вопреки официальной пропаганде, негативно оценивались российскими главнокомандующими. Не оправдались и уверения Тарговицких руководителей, которые заявляли, что после вторжения российской армии дворянство во всей Речи Посполитой примкнет к конфедерации и вверит себя в опеку Екатерины II - это осуществилось лишь в немногих местах, да и обычно с применением насилия. Не удалось также уничтожить, несмотря на большое превосходство, польско-литовской армии - хотя она отступила за Буг, но войска не были разгромлены, а ее боевой дух был на подъеме.

В руководящих кругах Петербурга стали рассматривать возможность переговоров со Станиславом Августом. В таком случае, можно сделать вывод, что решение Станислава Августа примкнуть к конфедерации было принято слишком быстро, более того, из российских источников следует, что король намеревался сделать это, несмотря на позицию членов Стражи. Как оказалось, своими действиям он добился противоположного ожидаемому результата - не только облегчил России усмирение страны, но и лишил себя хоть какого-нибудь влияния на дальнейшее развитие событий.

\section{Bibliografia}

\section{Źródła}

Arhiv Vnešnej Politiki Rossijskoj Imperii (AVPRI), f. 79/6, d. 1318, 1476, 1483, 1489, 1511

Rossiiskii gosudarstvennyi voenno-istoricheskii arkhiv (dalej: RGVIA), f. 41, op. 1/199, d. 174 Biblioteka Polska w Paryżu, sygn. 29, nr 8

Correspondance de Stanislas-Auguste avec Catherine II et ses plus proches collaborateurs (17641796), oprac. Z. Zielińska, Kraków 2015.

Pamiętniki króla Stanisława Augusta. Antologia, Warszawa 2013.

Sbornik Russkogo Istoričeskogo Imperatorskogo Obščestva (SIRIO), t. 47, St. Petersburg 1885.

\section{Opracowania}

Danilczyk A., Afera Dogrumowej a konsolidacja opozycji antykrólewskiej w latach 1785-1786, „Kwartalnik Historyczny” 111 (2004), nr 4, s. 47-81.

Dembiński B., Misja Ignacego Potockiego w Berlinie w roku 1792, „Kwartalnik Historyczny” 51 (1937), nr 1-2. 
Dembiński B., Polska na przełomie, Lwów 1913.

Górski K., Wojna 1792 r., Kraków 1917.

Korzon T., Dzieje wojen i wojskowości w Polsce, t. 3: Dokończenie epoki przedrozbiorowej, Warszawa 2003.

Michalski J., Opozycja magnacka i jej cele w początkach Sejmu Czteroletniego, w: idem, Studia historyczne z XVIII i XIX wieku, t. 1, Warszawa 2007, s. 285-304.

Michalski J., Stanisław August Poniatowski, Warszawa 2009.

Morawski K.M., Ignacy Potocki, cz. 1: 1750-1788, Kraków-Warszawa 1911.

Morawski K.M., Pogląd na opozycję magnacka między pierwszym rozbiorem a Sejmem Czteroletnim, w: Studia historyczne wydane ku czci prof. W. Zakrzewskiego, Kraków 1908, s. 374-387.

Rostworowski E., Sprawa aukcji wojska na tle sytuacji politycznej przed Sejmem Czteroletnim, Warszawa 1957.

Smoleński W., Konfederacja targowicka, Kraków 1903.

Soloviev S., Istoria padienija Polszi, Moskwa 2003.

Stanisław August i jego Rzeczpospolita. Dramat państwa, odrodzenie narodu, red. A. Sołtys, Z. Zielińska, Warszawa 2010-2011.

Ugniewski P., Ludwik XVI - Stanisław August. Propagandowe wizerunki równoległe, Warszawa 2014.

Wolański A., Wojna polsko-rosyjska 1792 r., Warszawa 1996.

Zahorski A., Spór o Stanisława Augusta, Warszawa 1990.

Zielińska E., Otto Magnus Stackelberg wobec projektu skonfederowania sejmu 1782 roku: przyczynek do praktyki polityki rosyjskiej w Rzeczypospolitej przed Sejmem Wielkim, „Kwartalnik Historyczny" 106 (1999), nr 4, s. 73-87.

Zielińska Z., Ambasador Otto Stackelberg w dobie wojny o sukcesję bawarska, w: eadem, Studia $z$ dziejów stosunków polsko-rosyjskich w XVIII wieku, Warszawa 2001, s. 136-159.

Zielińska Z., Geneza upadku orientacji rosyjskiej u progu Sejmu Czteroletniego w opinii ambasadora Stackelberga, „Wiek Oświecenia” (1999), nr 15, s. 57-93.

Zienkowska K., Stanisław August Poniatowski, Wrocław 1998.

Adam Danilczyk, dr, adiunkt w Instytucie Historii PAN. Zajmuje się historią drugiej połowy XVIII w., ze szczególnym uwzględnieniem stosunków polsko-rosyjskich, dziejów Wielkiego Księstwa Litewskiego oraz historii wojskowości tego okresu (adanilczyk@ihpan.edu.pl).

Adam Danilczyk, assistant professor at the Polish Academy of Sciences; his scholarly interests focus on the history of the second half of the 18th century, with particular emphasis on Polish-Russian relations, the history of the Grand Duchy of Lithuania and the military history of that period (adanilczyk@ihpan.edu.pl). 